\title{
The Current Situation, Reform Ideas and Concrete Measures of Skill Competition for College Students
}

\author{
Jun SUN, Yang-ming WANG \\ Library of Wuhan Polytechnic \\ Wuhan 430074, China \\ 5475968088@qq.com
}

\begin{abstract}
The construction of skill competition system plays an important role in improving students' professional quality and professional skills. Based on the general problems of the professional skill competition system in higher vocational colleges, this paper discusses the key points of the construction of the professional skill competition system. Through the reform of skill competition, this paper promotes professional and curriculum construction; through curriculum construction and professional construction, it enhances college skill competition. The curriculum construction and professional construction, and the college skill competition will promote each other and play a very important role in higher vocational education in the new era.
\end{abstract}

Keywords-college student; skills competition; the teaching reform; management mode

\section{INTRODUCTION}

The report of the 19th National Congress of the Communist Party of China pointed out that we should build an army of knowledge-based, skilled and innovative workers. The quality of workers is crucial to the development of a country and a nation. Whether a country can seize the commanding heights of development increasingly depends on the quality of workers. Labor and skill competitions are an important way to give full play to the enthusiasm, initiative and vigor of laborers in economic construction under the socialist system. It is the main and effective way to mobilize the working enthusiasm of laborers and stimulate the sense of professional honor. It is the most direct and effective carrier to improve the professional skills and accomplishment of laborers and enhance the competitiveness of enterprises[1].

\section{The Current Situation of College Students' SkILL COMPETITION}

\section{A. Many kinds of subject competitions lacking inheritance}

In recent years, a variety of discipline competitions have mushroomed to colleges and universities andcolleges and universities have responded by investing a large number of human, financial and material resources, organizing college students to participate in various disciplines at various levels and consuming a large number of teaching resources[2]. When a competition is held by a superior organization or enterprise, the school or a second-level college will organize students and teachers to participate in the competition, which costs a lot of energy and funds to complete the competition. Due to the limited time and energy, the competition will be abandoned after the end of the competition, and the similar competition in the next year shall be started from scratch, lacking continuity and inheritance.

\section{B. New problems in organizational management}

In the face of a variety of discipline competitions, the school has issued a series of discipline competition management methods, but it lacks a unified management mechanism. Secondary colleges or teachers can independently complete various competitions. They cannot make good use of school resources and they have a narrow coverage. Cooperation is needed within the school. As a result, the final competition results are often not ideal. For the instructors in charge of discipline competition, they need to spend a lot of time thinking about the following competition rules, content and equipment. For students, they are at a loss in the face of a variety of disciplines. Some excellent students take part in discipline competitions under the responsibility of different instructors at the same time, which results in limited benefits for students and no good results for excellent students. In the face of a lot of work and problems, in the current limited school hardware and software resources, teachers are under heavy tasks, so exploring effective discipline competition management and operation mode is particularly important.

\section{The goal of the vocational skills competition is not clear enough}

The purpose of participating in or holding various vocational skill competitions in higher vocational colleges is to stimulate students' interest, improve students' learning enthusiasm, promote the education and teaching work of schools, and test students' comprehensive ability level. It is not for the sake of competition, let alone for the performance. Many schools attach great importance to skill competitions at the provincial or national level, because the results of these competitions can often represent the honor of the school, which directly leads to the high degree of utilitarianism of the purpose of the skills competition held by the school, and makes the competition a burden for teachers and students, and even affects the normal teaching activities. 


\section{The teaching curriculum cannot fully meet the training requirements}

To carry out "innovation and entrepreneurship" education and vocational skill competition, we cannot separate them from daily teaching courses. In many theoretical course teaching activities, the teaching process is often designed in accordance with the established teaching materials. Teachers make teaching plans in line with the teaching plans strictly and teach according to the teaching plans. It is difficult to apply some vivid or practical cases close to students' life. As a result, the course content often lags behind, the class lacks vitality and flexibility, and the class effect is not good. The purpose of vocational skills competition and "innovation and innovation" education is to cultivate students. Whether they can be organically integrated into daily teaching courses is the key to improving the quality of talent training.

\section{E. Educational resources do not reach all students}

Only when more students participate in the innovation and entrepreneurship and vocational skill competition and experience the process of "innovation and entrepreneurship" and skill competition can they stimulate the motivation of learning and finally improve the comprehensive quality of students. But in some schools, "entrepreneurship and innovation" education, or competition for professional skills, has become an "elite game". Some schools pay great attention to all kinds of "creative" contest or vocational skills contest to obtain good grades for a few outstanding students, but care less about the improvement of all the students' practical and innovation ability training, which makes part of the excellent students take up most of the resources. The cultivation of their strength accounts for increasingly larger efforts, but the other students' "innovation entrepreneurship education and vocational skills competition" is less cared about, hence leading to big discounts on the overall quality of education.

\section{The MAIN IDEAS OF COLLEGE STUDENTS COMPETITION} REFORM

\section{A. The school and the secondary school have clear responsibilities and establish a competition management mechanism}

The university makes scientific plans for the organization and development of discipline competitions from the macro level, and sets up special institutions to be responsible for the overall management and promotion of the implementation. School competition management and overall planning combine the functions of the secondary school and is responsible for the specific organization and management of the competition, avoiding leading to secondary school between departments "fragmented, mutual communication, mutual credit", achieving resource sharing, strengthening exchanges and cooperation, working together to create an effective organization team, ensuring discipline race run efficiently[3]. The school, the secondary school and the instructor shall discuss together to formulate the discipline competition standard system of the school. Based on the overall plan of the school, the management methods of discipline competitions of different categories, levels and characteristics shall be formulated for different discipline competitions. We should encourage teachers and students to actively participate in discipline competitions related to their majors, standardize the procedures of discipline competitions, including registration, selection, and intramural competitions, etc. Different disciplines form a complete set of processes. The school discipline competition standard system and the different discipline competition management method formulation must fully solicit the instructor's suggestion, and in the follow-up 1 to2 years' operation practice, we should unceasingly revise it and the consummation will finally be determined.

\section{B. Instructors are encouraged to form interdisciplinary teams}

The instructor is the main force of the discipline competition personnel training. The instructor should also train the students' comprehensive ability of innovation and practice when training their professional knowledge. However, for some specialized skills, the instructor can't play a guiding role in all aspects and it is inevitable that the guidance of the students is random, so the subject competition can't make a substantial breakthrough. This requires the regular training of the front-line instructors, and at the same time we should encourage the formation of the guidance team across disciplines. In the same competition, each instructor specializes in one subject, so that the guidance can be targeted. For some competitions involving more than one field, instructors need classified guidance. For local colleges and universities, the faculty is already weak, and it is more necessary to concentrate the limited faculty on one or several topics in the competition, so as to achieve better results.

\section{Contest the formation of student teams}

Due to the heavy teaching and research tasks of teachers and the lack of communication between different disciplines, the discipline competition only involves the "nipping" elite cultivation of a few outstanding students. The university should expand the influence of discipline competition, publicize the significance of discipline competition to students through different channels, mobilize students to actively participate in various discipline competitions, and encourage students to form interdisciplinary teams to participate in competitions. Depending on the nature of the competition, the contestants may come from specific majors or from all arts, science and engineering majors in different schools of the university, so as to expand the influence of the competition project and solve the insufficient enrollment in secondary colleges. The registration of contestants can be carried out continuously and regularly throughout the year. The scope of selection can be broadened and the number of students can be expanded to select excellent contestants.

\section{Playing the role of trade associations}

The teams of participating students manage themselves to realize the natural inheritance of discipline competitions. The organization and management of most discipline competitions mainly rely on instructors or counselors. Due to the weak faculty, the workload of teachers is very heavy. In the discipline competition, if we can utilize the power of student groups to assist teachers to do the training work, to a certain 
extent, it will reduce the workload of the instructor;we will get twice the result with half the effort. By mobilizing the enthusiasm of students, a competition interest association is established, which is responsible for the recruitment and selection of competitions and the assistance of experimenters to manage the open laboratory, so that discipline competition activities become the normal activities of students and it can ensure the standardization of the whole competition training process of participating students. Students teach students, old members and new members form echelon, and through planning, step by step training to greatly mobilize the enthusiasm of student groups to participate in the discipline competition. Therefore students can be masters of the attitude to actively join in the discipline competition. By changing the term of office every year, the association will naturally realize the inheritance of the competition from generation to generation and avoid the fault.

\section{E. The guarantee mechanism of subject competition for college students}

The laboratory is open to discipline competition. It is not only a place for communication between instructors and participating teams, but also a fixed place for students' experiment and training. To achieve good results in discipline competition, the hardware support of the laboratory is indispensable. However, discipline competition and laboratory management belong to different departments. The instructor of discipline competition and the laboratory administrator tend to be different. In addition, the school has a strict management system for laboratory management, which makes it inconvenient for students to use the laboratory for discipline competition. The laboratory is open and student-centered. Schools, secondary colleges, instructors, student groups, competition assistants and experimental departments complement each other. The experimental department and the competition assistant manage the equipment for discipline competition together. Laboratory opening can be short term and long term. For short-term competitions, the opening time is from the start of the competition to the end of it, and for longterm projects such as national and provincial competitions, the opening time can be extended according to the competition cycle. The opening hours of the laboratory are in the spare time, specific opening hours are well planned, and special people are arranged to be on duty in turn. They are mainly responsible for the opening and closing of the laboratory, attendance, health, inspection and logging, and are inspected and supervised by the instructors every week.

\section{COLLEGE STUDENTS DisCIPLINE COMPETITION MANAGEMENT MODEL}

\section{A. To provide an organizational guarantee for college students' discipline competition management}

In the management discipline competition for college students, in order to give full play to the discipline competition in the applied talents training, we reflect the discipline competition management work of colleges and universities and it is necessary for them to participate in the competition subject management and to undertake the main body of subject contests, etc. To be specific, for the students discipline competition management, laboratory construction work can be a vice President who is directly responsible for, at the same time, it is necessary to build up the school educational administration department in colleges and universities, college or department linkage, grass-roots staff coordination management system, work content and responsibilities for different management subject. Colleges and universities need to clearly reflect in the discipline competition management rules and regulations to ensure the success of college students management work systematic discipline competition[4]. In college students, of course, the discipline competition in the management of school discipline competition, it is also important to the management and guidance work, therefore, in the perfect competition subject management system on the basis of college students, colleges and universities have set up college disciplines race guide agencies, which is responsible for the promotion of the discipline competition, organizations to participate in the work, while the grass-roots staff need the discipline competition content and targeted guidance to participating students. In addition, both the on-campus discipline competition and off-campus discipline competition cannot be held without the support of necessary funds. In this regard, it is necessary for colleges and universities to set up special funds for discipline competition to guarantee the acquisition of discipline competition resources, the improvement of teaching facilities and the insurance of material rewards.

\section{B. To promote the integration of subject competition into the teaching system}

In the management discipline competition for college students, strengthening academic competition and professionalism of the link between the teaching system for college students is of great significance for ascension, and therefore, colleges and universities attach importance to promoting competition disciplines in the teaching system; college students use "in order to promote teaching and learning" to improve the quality of personnel training in colleges and universities. Specifically, the group of needs for different university students design and organize activities of competition of different disciplines, such as for new students to effectively promote the new learning interest, create a good learning atmosphere, the basic knowledge of the different disciplines in colleges and universities subject contests, thus effectively deepening the students' own professional of cognition, and enhancing their professional knowledge that has learned about [5]. At the same time, in view of the development of students' professional ability, it is necessary for colleges and universities to realize the normalization of discipline competition activities, that is, around the different content of the competition, there will be monthly competitions, so as to ensure that discipline competition can continue to play an incentive role in the group of college students; we need not only attach importance to the school discipline in colleges and universities, but also emphasize competition, and the need to guide students to participate in provincial, national and international competition, and direction of course contests on the investigation to the students' professional ability of students professional ability to make a targeted training, thus in the 
process of students for subject competition, promoting students' professional quality of ascension. Compared with the discipline competitions held in the university, although these discipline competitions are more difficult, they are easier to stimulate students' desire to participate. Therefore, it is indispensable to use these discipline competitions as a platform to test and improve students' professional qualities.

\section{To construct the long-term incentive mechanism for college students' discipline competition}

In the discipline competition management of university students, it is the foundation that ensures the value of discipline competition of university students to do a good job in the publicity and organization of discipline competition and guide the group of university students to actively participate in discipline competition. Therefore, it is very important to build a sound long-term incentive mechanism for discipline competition of university students. In this regard, colleges and universities not only needs to pay attention to use material and spiritual incentives to stimulate the enthusiasm of college students to participate in course contests, but also needs to build incentive mechanism for college or department and grassroots staff groups, so as to give full play to the college or department in subject contests, grass-roots staff group subject contest in the role of the guide. Both the incentives of the college students' group, and institute or department, as well as grass-roots staff incentive, shall be conducted in the rules and regulations of college students' subject contest management, at the same time, it is necessary for colleges and universities to assess the various agencies on a regular basis, to evaluate the performance of each subject in the subject competition, and the performance in the event of a subject or outstanding contributions to individuals and departments in recognition, hence setting up the typical way and playing leading role of these individuals and departments.

\section{Relying on school-enterprise cooperation to hold discipline competitions}

In the course of university students' discipline competition management, it is of great significance to develop the function of university students' discipline competition by relying on the mode of school-enterprise cooperation. Specifically, depending on the university-enterprise cooperation subject contests can provide us with more resources for subject contests, meanwhile, the participation of social enterprise in design and hosting of subject contests is advantageous to the student to the forefront in the field of professional disciplines to understand knowledge and talent market demand, which can effectively improve students' professional attainment and innovative ability. Firstly, universities and social enterprises can hold discipline competitions by means of cooperation between universities and enterprises. Although social enterprises do not directly participate in the design and holding of college students' discipline competition activities in this way, they can provide financial support for it and strengthen students' understanding of social enterprises. Secondly, colleges and universities and social enterprises can hold subject competitions by means of evaluation and cooperation. Namely social enterprises involved in the review process of college students' subject competitions can standardize college students' evaluation and subject competitions from development, make talent market demand for the connection, let students review work that reflects a better professional discipline competition, ensure that the content of the competition subject related to the work practice of college students can get an objective evaluation. Thirdly, universities and social enterprises can hold subject competitions in the form of cooperative proposition. Relative to the first two kinds of cooperation mode, social enterprises in college students' subject contest design aspects of content, and it also determines college students' subject competitions in terms of competition content based on this kind of cooperation mode. It also reflects investigation direction, which is able to discipline development, college students' professional practice ability, etc. to better reflect, so that the college students' subject contests reflect the characteristics of the theory with practice[6]

\section{CONCLUSION}

Competition disciplines management of college students is of great importance for improving the quality of applied talents in colleges and universities, therefore, colleges and universities need to provide an organizational guarantee for the development of college students' subject competition management, financial security; to promote college students' subject contest closely integrated with professional teaching implementation. At the same time, colleges and universities should also attach importance to stimulating the enthusiasm of students to participate in the activities of course contests. Each department organization disciplines competition's enthusiasm, and relies on the design and hosting of cooperation between colleges and students' subject competitions and social unit to ensure that the value of college students' subject competitions and function fully reflect and give play to.

\section{REFERENCES}

[1] XIONG Kuang-han. Research on the Significance of College Teaching Competition and Brand Demonstration Effect [J]. China Higher Education Research,2009(4).

[2] YUAN Hong. Guiding Classroom Teaching Reform and Quality Improvement by Teaching Competition of Young Teachers [J]. China University Teaching,2017(11).

[3] PENG hong-ya. Encourage Engineering College Students to Participate in Discipline Competitions and Promote High-quality Employment [J]. Henan Education (Higher Education),2014(6)

[4] LI Su-bei. Promoting Curriculum Construction and Cultivating Students Innovation Ability Through Subject Competition. University Mathematics, 2009.

[5] TANG Li-guo. Promoting the Reform of Practical Courses and the Cultivation of Innovative Talents in Colleges and Universities Through Subject Competition. Education and Profession.2008.

[6] YU huadong. Research on Elements of College Students' Innovation Ability. Journal of Taiyuan Normal University.2011. 